\title{
The Cadets Experience in Applying Standard Marine Communication Phrases During Training on Board Ship
}

\author{
Nursyam \\ Politeknik Pelayaran Barombong, Makassar, Indonesia \\ Jalan Permandian Alam No. 1 Makassar \\ e-mail:nursyamrto@gmail.com
}

\begin{abstract}
The aim of the International Maritem Organization Standard Marine Communication Phrases (SMCP) is to get round the problem of language barriers at sea and to avoid those misunderstandings which can cause accidents. But, is it used at sea? The key to improve verbal communication is in the recruitment of seafarers who have an understanding of the English language. The training cadets are going to be officers on board ship, otherwise their English communication have to be well prepared weather in campus or on board ship. The objective of this research was to find out the cadets' experience in applying Standard Marine Communication Phrases (SMCP) during training on board ship.This research applied qualitative description. The respondents were the cadets of Barombong Maritime Polytechnic who were sailing on any ships as training cadets. The respondents consisted of 34 Nautical cadets of Batch 58. The research data were collected by questionnaire and analyzed by using goggle form to reveal the cadets' experience in using standard marine communication phrases (SMCP) on the ship. The research result conveyed that the cadets were seldom to use English, particularly SMCP on board ship generally, in fact around $70 \%$ of the respondents who were sailing in domestic routes reported that SMCP was used to communicate when their ships passed with foreign ships. Otherwise, more than $80 \%$ stated that English is important for seafarers' profession and SMCP is regarded as one of the communication tools to avoid miscommunication at sea.
\end{abstract}

Keywords: Standard Marine Communication Phrases, Cadets Experience, Appliying.

\section{Introduction}

Good communication is mandatory for maritime safety, security, safe navigation and maritime business. Seafarers need communication on board ships and this communication is mostly done through English because the maritime professionals come from different countries speaking various languages. As the seafarers are from multicultural background, they need a common language to communicate and English is used for this purpose. Since maritime professionals have to move to all parts of the world, they need to acquire the skills of effective communication. Moreover, seafarers need to communicate from ship to ship and from ship to shore. For example, an endangered ship may seek the help of a pilot to come to the ship and rescue them. This communication is basically done in English. So, for safe navigation, learning English is very urgent for seafarers. Besides, seafarers can use English as an international maritime language. In fact, using a common language (English) provides some opportunities to the seafarers. Firstly,

This paper is presented in The $4^{\text {th }}$ International Conference on Maritime Education and Training

October $8^{\text {th }}$, 2020, Makassar, Indonesia 
they can improve their communication abilities. Secondly, English can facilitate social harmony. Finally, English can consolidate teamwork on the board.

As David Patraiko (2015) stated that communication and navigation are actually related. Right from the start of voyage planning, the navigator needs up-to-date information that will affect the passage of the ship, such as chart corrections, Maritime Safety Information (MSI) and weather reports; not to mention charterer's instructions. This information requires to be effectively communicated to the vessel and presented in a format that aids decision-making. During the voyage, communication is essential not only among the bridge team onboard, but also with shore authorities such as VTS, and, occasionally, with other ships [8].

The competence to properly deliver information by spoken as well as by written communication is essential not only to the safety of ships' crews, visitors and passengers, but also to the well being of crews. It would seem that the standard of English of some seafarers is so bad that they have difficulty in communicating not only between themselves but also with agencies outside the ship. The aim of the IMO Standard Marine Communication Phrases (SMCP) is to get round the problem of language barriers at sea and avoid those misunderstandings which can cause accidents.

International Maritime Organization has analyzed some the incident reports to discover if there are any lessons to be learned for the future. A lot of explored accidents are led by operational issues such as improper procedure, maintenance and design, although communication difficulties also often occur in circumstances that are due to cultural differences and language barriers [1]. In line with that, poor skills in the English language are a significant factor in the human errors that lead to about 80 percent of accidents at sea [11]. IMO states that about 80 percent of accidents at sea are caused by human error, and one of the main causes of these accidents and incidents, some involving loss of life, a large number of injuries and extensive financial loss, is the crew poor standard of Maritime English [13]. Ugulru at all (2015) also stated the most significant causes of human error-related grounding accidents are, lack of communication in BRM, position-fixing application errors, lookout errors, interpretation errors, use of improper charts, inefficient use of bridge navigational equipment, and fatigue [12]. Therefore, (Trenker, in Alfiani, 2010) declared that seafarers must better apply the English language as a standard communication at sea and as required by IMO. "Seafarers need to make more use of the International Standard Marine Communication Phrases-SMCP [1]. In fact, a research finding by Irawan (2019), conveyed that the officers are still lack of understanding and using of SMCP on board ship. which led to navigation incident [7].

There are some incidents at sea that show the important of effective communication. The following incident as written by Bhanawat in Marine Insight:2020 was caused by the lack of communication among the team on board.

A vessel was transiting Suez Canal with pilot onboard where she was supposed to be navigating along the centre line of the channel, however as she drifted away from the centre line the pilots and bridge team used corrective helm and engines to counter it. By the time the vessel had swung considerably and it neared another bank on the opposite side. The stern of the vessel brushed and contacted with rocky bottom. A heavy thud was heard and vibrations felt on the wheelhouse and engine room as well. Speed of the vessel dropped and picked up again. All ship staff noticed the vibrations. Engine room called up bridge to confirm if everything was in order. Both the officers on watch confirmed with the pilot if everything was in order to which pilot responded affirmatively. The vessel had picked up

This paper is presented in The $4^{\text {th }}$ International Conference on Maritime Education and Training 35 
speed again and resumed the canal transit. The senior most officer on watch neither called master nor discussed it later on with him. However, below the waterline the forward part of the hull suffered damages and thus her strength was reduced considerably in the area of impact. Slight deformation was there but below the waterline. The vessel crossed the canal and while she was loading in load port a large thud was heard again and the officer on watch noticed water rushing in ballast tank No. $1,2,3$ on Port Side. Due to continual stresses on a damaged, deformed and fatigued hull the weak zone crumbled and gave away.

The root cause upon investigation was lack of communication among onboard team as they failed to assess damages through ballast tank inspection after a contact and report the shore based management about the same. A strong channel of communication here between team onboard and shore staff could have saved off hire charges and the loss of reputation the ship owners suffered [3].

The key to improved verbal communication is in the recruitment of seafarers who have an understanding of the English language; in education in the art of effective communication and in the correct use of the English language in the maritime environment; and in a program of regular testing in their knowledge of the English language. Moreover, while IMO has clearly made substantial efforts to strengthen provisions concerning Maritime English requirements, this does not necessarily mean that the graduates of maritime academies are consistently well prepared and that the levels of competence attained during training match the sufficient levels envisaged [1]. However, if there is a high motivation from cadets to put an effort into practicing their English language, it will be more helpful in improving their communication skills.

The cadets as the future officers on board ships have been prepared with maritime English curriculum adopted from IMO MC 3.1 [5]. which consists of General Maritime English and Specific Maritime English. Standard Marine Communication Phrases are the substance of the specific Maritime English material. The Indonesian cadets for Third Class Certificate are trained to use English in the education and training institute for around 192 classroom hours based on curricular and cocurricular activities [9]. From this limited duration, they are supposed to apply English language on board ship during their training as well as on their professional job as seafarers.

The cadets are supposed to conduct on board training on ocean going ships, otherwise, the foreign shipping companies which received training cadets from Indonesia are limited, therefore, they join Indonesian ships. On board these ships, they are expected to practice English with the crew on board ships and observe the use of English for external communication. This experience will motivate the cadets to be more active in learning English for their profession as seafarers.

\section{Research Method}

This research used qualitative research method. AS Quinn, 2002 defined that Qualitative research is categorized by its purposes, which relate to understanding some feature of social life, and its methods which (in general) generate words, rather than numbers, as data for analysis [10]. In this case the researcher collected data related to the use of English (SMCP) on the ships where the cadets conducted training. The data were collected and analyzed by using questionnaire in google form and some of the respondents were interviewed to get deeper answer and explanation about the use of SMCP on board ship. This research was conducted at Barombong Maritime Polytechnic. The respondents

This paper is presented in The $4^{\text {th }}$ International Conference on Maritime Education and Training 36 
were 34 cadets of Third Class Certificate Program, who had joined different types of ships for training purposes which sailed in domectic routes.

\section{Results and Analysis}

The cadets' experience in using English particularly the standard marine communication phrases are divided into two basic parts. The use of English for external communication and the use of English on board ship with other crew.

\subsection{The use of English for external communication}

The SMCP is used for external communication on distress condition, urgency, safety and routine message. There are some questions to gather the relevant data.

The first group of questions were to find out the use of English (SMCP) related to the use of SMCP when the ships required assistance on distress and urgency conditions, safety communication related to weather forecast, routine communication when requesting pilot and when the ships are passing with foreign and domestic ships. The cadets' responses are illustrated by the following graph.

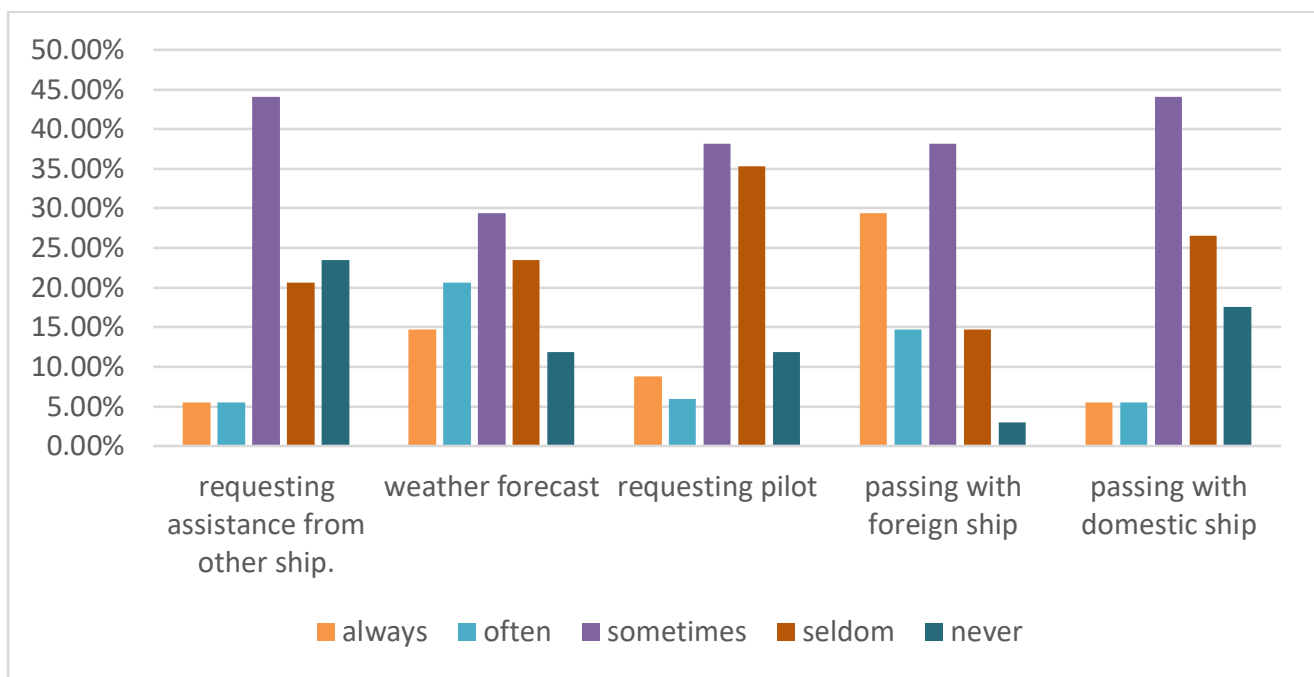

Figure 1. External Communication for Requesting Assistance, Safety and Routine Communication

The result revealed that English SMCP was rarely used when the ships required assistance from other ships, when their ships were passing with domestic ships and when they requested pilot. The data about the use of English for weather forecast and for communicating with foreign ships showed a little bit diffesrent in the percentage. It leads to positive result of the English use on board ship for external communications. This data implies that the seafarers use English depend on their condition.

Communication with vessel traffic servise is one of the external communication. The findings showed by the following graph. 


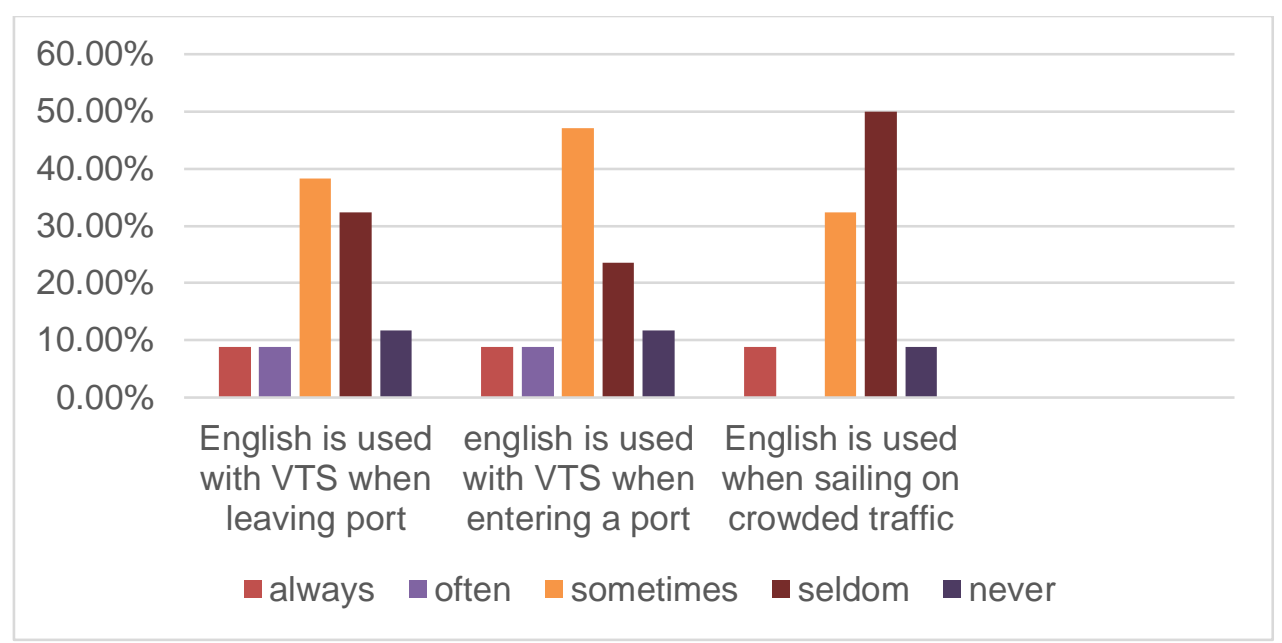

Figure 2. Communication with Vessel Traffic Service

In line with the previous group of questions, the findings for the use of English with VTS demonstrated that the cadets seldom use English with VTS to report when they are going to leave and enter a port as well as communicating with the VTS in crowded traffics.

After interviewing some of the cadets who responded that they used English on this situation, it was found that their sailing routes were in Malacca Strait which is one of the very busy International sailing route. This result conveyed that English will be used when the authority and regulation required it. Otherwise, the seafarers must use SMCP as often as possible in preference to other wording of similar meaning; as a minimum requirement users should comply as closely as possible to their wording in connected situations. In this way they are intended to become an acceptable safety language, using English for the verbal interchange of intelligence among individuals of all maritime nations on the many and varied occasions when precise meanings and translations are in doubt, increasingly evident under modern conditions at sea.(SMCP;2004)

\subsection{On Board Communication}

The second category of result was to illustrate the use of English on board ship or internal communication. The questions were divided into two parts; the use of English in general routine activities and the use of English for daily conversation. The following graph illustrates the use of SMCP on board ship communication with other crew.

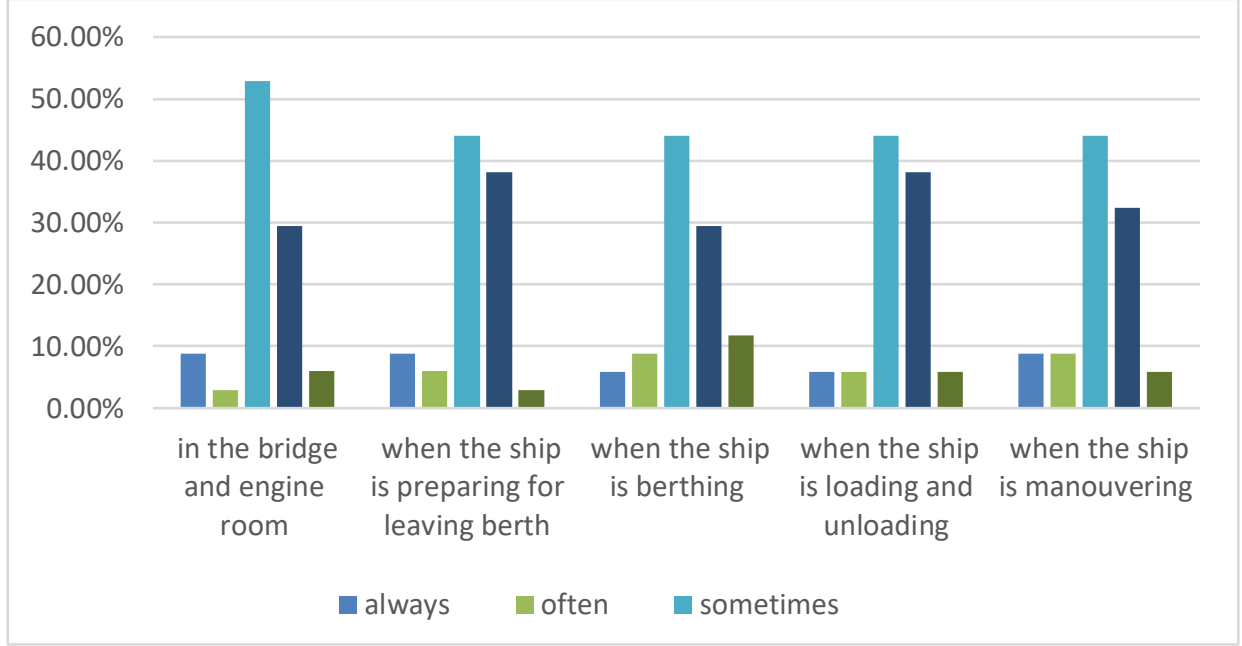

Figure 3. Using SMCP On board Communication

This paper is presented in The $4^{\text {th }}$ International Conference on Maritime Education and Training 
The result figures out that English SMCP are used very limited in internal activities on board ship. This finding requires the researcher to dig more reasons for this condition. It implies some indicators; the officers' knowledge of English is low or because the crew are all Indonesian.

The next category of questions was aimed to dig the use of English in their daily activities with the Officers on board ship. The description was figured out at the following graph.

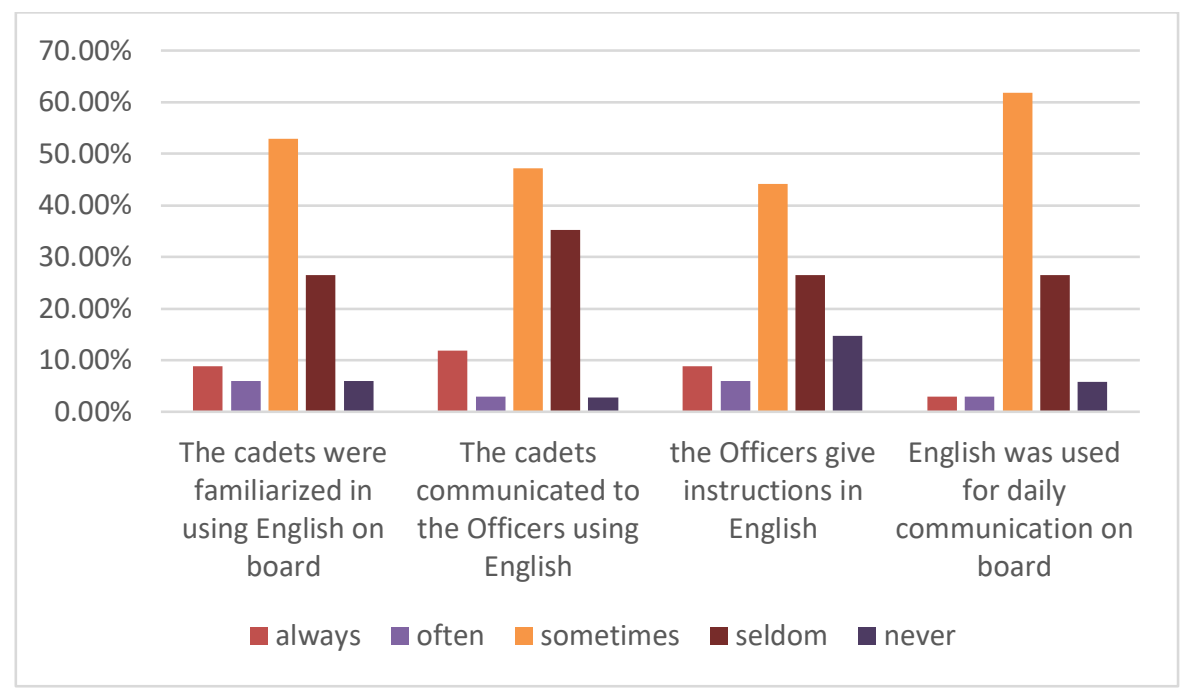

Figure 4. Using English for Daily Activities on Board Ship

The cadets as the respondents in this reserch were sailing on Indonesian ships which had all Indonesian crew, therefore it is not surprising when they responded that they seldom used English on board. Only few of them used English for daily activities. This data showed that English was not applied by the seafarers on Indonesian ships.

The findings relate to the previous studies on the ship's crew competence in using SMCP on MT Nariva which shows that they have limitation in using SMCP.

After giving some questions related to the use of English (SMCP) internally and externally, as additional information, the respondents were requested to give their perception on the importance of English (SMCP) at sea. The result showed that they had positive perception on the use of English as a tool of communication on board ship.

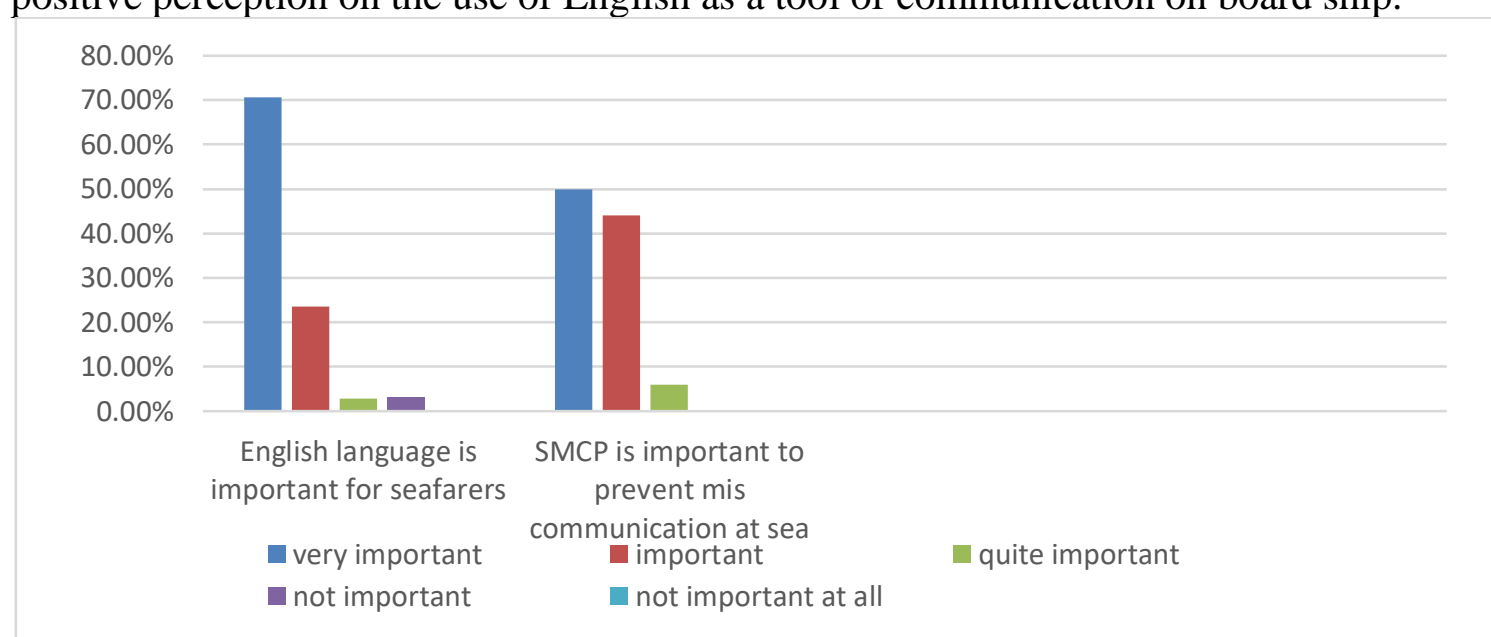

Figure 5. The Cadets' Perception on the Importance of English and SMCP at Sea

This paper is presented in The $4^{\text {th }}$ International Conference on Maritime Education and Training 


\section{Conclusion}

The cadets had limited space in appliying English (SMCP) when they conducted their training on Indonesian shipping company

The cadets require more English training to build their self confidence in order to have opportunity to join on foreign shipping company where they will be able to use English.

The officers on board ship, particularly in Indonesian ships, have limited English, therefore, they can not apply English properly on board ship.

\section{Suggestions}

The cadets should be facilitated more English training in order that they have sufficient English and self confidence to join on Foreign Shipping company.

There should be further research on the investigation of the Indonesian seafarers' competence in English language, particularly in using SMCP.

\section{References}

[1] Alfiani,D. Multinational and Multicultural Seafarer and MET students: a SocioCultural Study for Improving Maritime Safety and the Education for Seafarers. World Maritime University, 2010

[2] Aprizawati, Aswand. Crews' Perceptions of Maritime English Usage at RORO Bengkalis. Inovish Journal, 2018; Vol.(3): No.2.

[3] Bhanawat, Abhisek. Two Incidents That Prove Improper Communication Leads to Accidents At Sea. Marine Insight.2020 (https://www.marineinsight.com/marinesafety/two-incidents-that-prove-improper-communication-leads-to-accidents-at-sea/)

[4] Evangelos, Tores. Language Barriers and Miscommunication as A Cause of Maritime Accidents. Merchant Marine Academy of Macedonia.

[5] IMO Model Course 3.17. Maritime English. London. 2015

[6] IMO Standard Marine Communication Phrases (SMCP 2001), IMO, London, 2001): http://www.pfri.hr, www.imo.org.

[7] Irawan, Naufal. Analisis Kemampuan Crew Menggunakan Standard Marine Communication and Phrases (Smcp) Di Mt. Nariva. Politeknik Ilmu Pelayaran Semarang. 2019

[8] Patraiko, David. Communication's what you need. The Navigator. February 2015 Issue no. 08..2015

[9] PK.07-BPSDM Perhubungan tahun 2016

[10]Quinn, Michael. Cochran, Michael. A Guide to Using Qualitative Research Methodology. Medecins sans frontiers 2002

[11] Safety at sea, 2018.

[12] Uğurlu, O, E. Köse, U. Yıldırım and Bazar, E. Analysis Of Grounding Accidents Caused By Human Error Journal of Marine Science and Technology, Vol. 23, No. 5, pp. 748-760 (2015) DOI: 10.6119/JMST-015-0615-1.

[13]Ziarati, R. A report on IMO MSC 82 to IMarEST for consideration to Technical Affairs Committee, IMarEST news. 2007. 